\title{
Relationship between Solubility, Moisture Sorption Isotherms and Morphology of Chitosan/methylcellulose Films with Different Carbendazim Content
}

\author{
Dang Thi Mong Quyen \\ Postharvest Technology Research Institute, Chiang Mai University, Chiang Mai, Thailand \\ College of Food Industry, Da Nang, Vietnam \\ Tel: 66-53-944-031_E-mail: mongquyen76@gmail.com
}

Joomwong Adisak

Division of Biotechnology, Faculty of Science, Maejo University, Chiang Mai 50290, Thailand

Tel: 66-53-873-540 E-mail: joomwong@mju.ac.th

Pornchai Rachtanapun (Corresponding author)

Division of Packaging Technology, Faculty of Agro-Industry, Chiang Mai University, Chiang Mai, Thailand

Materials Science Research Center, Faculty of Science, Chiang Mai University, 50200, Thailand

Tel: 66-53-948 228 E-mail: p.rachta@chiangmai.ac.th

Received: February 13, $2012 \quad$ Accepted: February 29, $2012 \quad$ Online Published: April 26, 2012
$\begin{aligned} & \text { doi:10.5539/jas.v4n6p187 } \\ & \text { URL: http://dx.doi.org/10.5539/jas.v4n6p187 }\end{aligned}$

\begin{abstract}
Chitosan and methylcellulose are popular biopolymer materials that are used in films and as coatings for food products. The addition of carbendazim which is an antimicrobial agent to these biopolymers can lead to changes in solubility, moisture sorption isotherm and the morphology of the chitosan/methylcellulose films (C/MC) at various carbendazim contents $(0.8 ; 1.6 ; 3.2$ and $4.8 \mathrm{~g} / 100 \mathrm{~g}$ of solid $\mathrm{C} / \mathrm{MC}) . \mathrm{C} / \mathrm{MC}$ films with carbendazim had lower solubility values than control films. The moisture sorption isotherms of $\mathrm{C} / \mathrm{MC}$ films incorporated with carbendazim were examined for water activities in the range of $0.11-0.86$ at $25 \pm 0.5^{\circ} \mathrm{C}$. These isotherms showed that carbendazim content affected the equilibrium moisture content (\%EMC) of the films and the \% $\mathrm{EMC}$ of all films dramatically increased above $\mathrm{a}_{\mathrm{w}}=0.66$. The $\mathrm{C} / \mathrm{MC}$ films incorporated with carbendazim exhibited lower $\% \mathrm{EMC}$ than that of the control films under all relative humidity conditions. The changes of the moisture sorption isotherms of the $\mathrm{C} / \mathrm{MC}$ films at different carbendazim contents can be related to changes in cross-section morphology of these films. By understanding the behavior of the sorption isotherms, it is possible to predict the moisture sorption properties of $\mathrm{C} / \mathrm{MC}$ films via moisture sorption empirical models. The Guggenheim-Anderson-deBöer (GAB), Brunauer-Emett-Teller (BET) and Oswin sorption models were used to fit the experimental data. Our results show that the GAB model was the best-fit model for C/MC films incorporated with carbendazim at $25 \pm 0.5^{\circ} \mathrm{C}$.
\end{abstract}

Keywords: Biopolymer, Carbendazim, Chitosan, Methylcellulose, Sorption isotherm

\section{Introduction}

Chitosan is the second most abundant polysaccharide on earth and has inherent antimicrobial activity Goldberg et al., 1990). Furthermore, it provides films with good mechanical and oxygen barrier properties (Caner et al., 1998). However, chitosan has poor tensile strength properties when wet. It has a rigid, high elastic modulus but has poor elongation properties (García et al., 2004). Methylcellulose (MC) is a nonionic cellulose with excellent film-making properties including a high solubility and efficient oxygen and lipid barrier properties (Donhowe and Fennema, 1993). These materials are also selectively permeable to $\mathrm{CO}_{2}$ and $\mathrm{O}_{2}$, and hence, retard the respiration and ripening of many fruits and vegetables by limiting the availability of $\mathrm{O}_{2}$ (Park et al., 1993). Blending 
methylcellulose with chitosan allows for the production of new materials with the benefits of both able to limit these weaknesses of each material when used individually. Film flexibility has been shown to increase with increasing MC content (García et al., 2004). Several studies have been carried out evaluating mechanical properties including water vapor permeability and the moisture sorption isotherm of chitosan, methylcellulose and chitosan blended films (Chen et al., 1996; Donhowe and Fennema, 1993; Nazan Turhan and Sahbaz, 2004; Park et al., 1993; Sangsuwan et al., 2008). However, little research has been done on the moisture sorption properties of chitosan or chitosan/methylcellulose materials incorporated with antimicrobial agents.

Moisture sorption isotherms are an important property to evaluate the effect of relative humidity (RH) on film performance (Cadden, 1988; Lai and Padua, 1998). Since the addition or removal of water may cause phase transitions in the macromolecular structure (Schwartzberg, 1986; Torres, 1994), knowledge of sorption isotherms is important for predicting water sorption properties of hydrophilic films, stability and quality changes during packaging and storage of intermediate and high moisture foods (Kulchan et al., 2010). There are about 23 mathematical models which describe water sorption isotherms of food systems materials, but no single model gives accurate results throughout the whole range of water activity, or for all types of food systems (Al-Muhtaseb et al., 2004; Chirife and Iglesias, 1978). The Guggenhein-Anderson-de Boer (GAB), the Brunauer-Emmett-Teller (BET) and the Oswin models have been widely used to describe the water sorption behaviors of films and foods (Ludwiczak and Mucha, 2010; Mali et al., 2005; Rachtanapun et al., 2010; Rachtanapun and Tongdeesoontorn, 2009; Tongdeesoontorn et al., 2009; Velaquez de la Cruz et al., 2001; Villalobos et al., 2006).

In the scope of this study, carbendazim (methyl-2-benzimidazole carbamate - $\mathrm{C}_{9} \mathrm{H}_{9} \mathrm{~N}_{3} \mathrm{O}_{2}$ ), a widely used broad-spectrum benzimidazole fungicide that plays a very important role in plant disease control, was incorporated with $\mathrm{C} / \mathrm{MC}$ films to improve the antimicrobial activity. Carbendazim has also been used directly to control fungi and diseases of plants and fruits in postharvest food storage, in seed pre-planting treatment, and as a fungicide in paint, paper and wood. This benzimidazole fungicide plays a very important role in the control of fungi and diseases on plants and fruits. The fungicidal activity of benomyl is due to the presence of carbendazim (Clemons and Sisler, 1971). Blending carbendazim into C/MC films to create an antimicrobial environment on the surface of the material is a new trend in fruits and food packaging development. There are no reports on the effect of carbendazim concentration on the properties of $\mathrm{C} / \mathrm{MC}$ based films.

Therefore, the objectives of this study were to evaluate the water sorption isotherms of C/MC films incorporated with carbendazim and fit the experimental data to the moisture sorption models. Knowledge of these results is important for application the antimicrobial films in fruit storage.

\section{Material and Methods}

\subsection{Materials}

Chitosan with a degree of deacetylation of $90 \%$ and purity $>99.75 \%$ was purchased from Bannawach Bio-line Co. Ltd., Thailand. Methylcellulose (viscosity 10-25 mP.s, Methocel \# 64605) was purchased from Sigma-Aldrich, USA. Polyethylene glycol (PEG) 400 was purchased from Vichavit, Thailand. Carbendazim $(50 \% \mathrm{w} / \mathrm{v})$ was purchased from BaSF Co., Thailand, and ethanol (99.8\%) and acid acetic (98\%) were purchased from MERCK, Germany.

\subsection{Films Preparation}

The chitosan solution was prepared by dissolving $1.5 \mathrm{~g}$ of chitosan in $100 \mathrm{~mL}$ of $1 \%$ acetic acid solution. One gram of methylcellulose was dissolved in $100 \mathrm{~mL}$ of ethanol:water (1:3). Solutions of chitosan and methylcellulose were then mixed in a beaker with a stirrer. One gram of polyethylene glycol (PEG) 400 was used as a plasticizer (Sangsuwan et al., 2008a). Carbendazim with various contents $(0.8 ; 1.6 ; 3.2$ and $4.8 \mathrm{~g} / 100 \mathrm{~g}$ solid of C/MC) was blended into the $\mathrm{C} / \mathrm{MC}$ film-solution. The solutions were then filtered, cooled down and degassed. The film-forming solutions were poured onto glass plates $(14.5 \mathrm{~cm}$ diameter) and calculated to obtain a constant thickness for the films of $0.06 \pm 0.005 \mathrm{~mm}$. Then, the films were dried at ambient temperature for 48 to 72 hours.

\subsection{Film Solubility}

Films were cut into square $1 \mathrm{~cm} \times 1 \mathrm{~cm}$ pieces and dried to constant weight in a vacuum oven at $60^{\circ} \mathrm{C}$ for 24 hours to obtain the initial film dry weight $\left(\mathrm{W}_{\mathrm{d}}\right)$. Each film was then placed in a bottle containing $20 \mathrm{ml}$ distilled water for 24 hours under gentle agitation and controlled temperature at $25^{\circ} \mathrm{C}$. Films were then dried under the same conditions to obtain the dry weight of water - leached film $\left(\mathrm{W}_{\mathrm{ws}}\right)$. Film solubility was calculated using equation 1 :

$$
\% \text { Solubility }=\left(\mathrm{W}_{\mathrm{d}}-\mathrm{W}_{\mathrm{ws}}\right) \times 100 / \mathrm{W}_{\mathrm{d}}
$$




\subsection{Sorption Isotherms}

Water sorption isotherms were determined using the method of discontinuous registration of weight changes in a static system. Moisture sorption isotherms of the chitosan/methylcellulose films incorporated with carbendazim were determined by placing film samples into a controlled humidity environment at a constant temperature until an equilibrium state was obtained.

Film specimens ( $30 \mathrm{~mm} \times 30 \mathrm{~mm}$ ) were pre-dried for 7 days in vacuum desiccators containing silica gel beads and then were placed at $25 \pm 2^{\circ} \mathrm{C}$ over saturated salt solutions in separated desiccators each having the desired relative humidity conditions $(11.2 ; 33.5 ; 44.5 ; 53.1 ; 66.4 ; 75.1$ and $85.5 \mathrm{RH})$ (Table 1$)$. Weights of film specimens were determined daily and when the difference between two consecutive weightings was approximately equal (not greater than $0.1 \%$ of the sample weight), it was assumed that an equilibrium condition had been reached. The moisture contents of the films were then determined by oven drying at $105^{\circ} \mathrm{C}$ for 10 hours (Mali et al., 2005). The initial moisture content of a sample at each specific relative humidity was determined using equation 2 (Rachtanapun, 2007):

$$
\mathrm{M}_{i}=\frac{\mathrm{W}_{e}-\mathrm{W}_{D}}{\mathrm{~W}_{D}} \times 100 \quad(\mathrm{~g} / \mathrm{g} \text { dry solids })
$$

Where $\mathrm{M}_{i}$ is the initial moisture content of the film $(\mathrm{g} / \mathrm{g})$

$\mathrm{W}_{i}$ is the initial weight of the film (g)

$\mathrm{W}_{D}$ is the weight of the film after drying $(\mathrm{g})$

The equilibrium moisture content was next calculated as equation 3 (Rachtanapun et al., 2010).

$$
\mathrm{M}_{e}=\frac{\mathrm{W}_{e}}{\mathrm{~W}_{i}}(\mathrm{Mi}+1)-1(\mathrm{~g} / \mathrm{g} \text { dry solids })
$$

Where $\mathrm{M}_{e}$ is the equilibrium moisture content of the film (g/g dry solids)

$\mathrm{W}_{e}$ is the equilibrium of the film (g)

$\mathrm{W}_{i}$ is the initial weight of the film (g)

$\mathrm{M}_{i}$ is the initial moisture content of the film $(\mathrm{g} / \mathrm{g})$

\subsection{Morphology Observation}

The cross-sectional morphologies of the C/MC films with and without carbendazim were examined using a scanning electron microscope (JEOL, JSM-5910LV, Tokyo, Japan) operated at $15 \mathrm{kV}$. Cross-sectional samples were prepared by fracturing films in liquid nitrogen. Then, samples were mounted on the metal grids and coated with gold under vacuum prior to analysis. The cross-sectional morphologies were observed under 2500 fold magnification.

\subsection{Data Analysis}

The Guggenheim-Anderson-deBöer (GAB), Brunauer-Emett-Teller (BET) and Oswin sorption models then were used to fit chitosan/methylcellulose films sorption isotherm data using the following equations (Cervera et al., 2004; Chirife and Iglesias, 1978; Rachtanapun et al., 2010).

The GAB model:

$$
\mathrm{M}=\frac{\mathrm{M}_{\mathrm{o}} \mathrm{Cka}_{\mathrm{w}}}{\left(1-\mathrm{ka}_{\mathrm{w}}\right)\left(1+(\mathrm{C}-1) \mathrm{ka}_{\mathrm{w}}\right)}
$$

Where $\mathrm{M}$ is the equilibrium moisture content on dry basic at a water activity $\left(\mathrm{a}_{\mathrm{w}}\right)$

$\mathrm{M}_{\mathrm{o}}$ is the monolayer moisture value ( $\mathrm{g}$ water/g solids)

$\mathrm{a}_{\mathrm{w}}$ is water activity

$\mathrm{C}$ and $\mathrm{k}$ are the equation parameters, both are temperature dependent and related to the interaction energy between water and films.

The BET model: 


$$
M=\frac{M_{0} \mathrm{Ca}_{\mathrm{w}}}{\left(1-\mathrm{a}_{\mathrm{w}}\right)\left(1+(\mathrm{C}-1) \mathrm{a}_{\mathrm{w}}\right)}
$$

Where $\mathrm{M}$ is the equilibrium moisture content on dry basic at a water activity $\left(\mathrm{a}_{\mathrm{w}}\right)$

$\mathrm{M}_{\mathrm{o}}$ is the monolayer moisture value ( $\mathrm{g}$ water/g solids)

$\mathrm{C}$ and $\mathrm{k}$ are the equation parameters

The Oswin model:

$$
\mathrm{M}=\mathrm{k}\left[\mathrm{a}_{\mathrm{w}} /\left(1-\mathrm{a}_{\mathrm{w}}\right)\right]^{\mathrm{C}}
$$

Where $\mathrm{M}$ is the equilibrium moisture content on dry basic at a water activity $\left(\mathrm{a}_{\mathrm{w}}\right)$

$\mathrm{C}$ and $\mathrm{k}$ are the equation parameters

The parameters of the equations were estimated by using Kyplot 2.0 for Windows (Kyence Inc., Japan). The value of the root mean square percent error (\%RMS) represents the fitting ability of a model in association with the number of data points (Suppakul, 2006).

\section{Results and Discussion}

The water permeability and water absorption properties of films are involved with the solubilization and diffusion of molecules through the film matrix. Therefore, the affect of carbendazim content on C/MC film solubility and moisture sorption isotherms modified the films solubility as is presented in Fig. 1. The C/MC films with carbendazim had lower solubility values than in the control film. The films solubility decreased from 64.3 to $56.9 \%$ as carbendazim content increased from 0 to $1.6 \mathrm{~g} / 100 \mathrm{~g}$ of solid $\mathrm{C} / \mathrm{MC}$, respectively, and then increased slightly to $60.3 \%$ at $4.8 \mathrm{~g} / 100 \mathrm{~g}$ of solid $\mathrm{C} / \mathrm{MC}$. The pure film incorporated with $1.6 \mathrm{~g}$ carbendazim achieved the lowest solubility value.

Moisture sorption isotherms for the $\mathrm{C} / \mathrm{MC}$ films were determined in a controlled relative humidity system (0.11-0.86 $\left.\mathrm{a}_{\mathrm{w}}\right)$ using saturated salt solutions. For all films stored in controlled RH desiccators and monitored over time, moisture sorption increased rapidly in the initial stages and then lower amounts of water were absorbed with increasing time. When the moisture content of the films reached a plateau, this indicated the film's moisture had equilibrated with the relative humidity in each condition. At higher relative humidity's, a increased time was required to reach equilibrium. For films stored under $44.5 \% \mathrm{RH}$, the equilibrium was reached within 5 days while it took 7 days for films stored at $85 \% \mathrm{RH}$.

The change in the moisture sorption isotherms for $\mathrm{C} / \mathrm{MC}$ films with and without carbendazim is shown in Fig. 2. All of these films can be classified as having a type II sigmoidal isotherm. The equilibrium moisture content of all of these films dramatically increased above $\mathrm{a}_{\mathrm{w}}=0.664$. The presence of carbendazim affected the moisture sorption isotherms of the chitosan/methylcellulose films. C/MC films with carbendazim had lower equilibrium moisture contents than in the control film (without carbendazim). The equilibrium moisture content of the $\mathrm{C} / \mathrm{MC}$ films decreased when the level of carbendazim content increased from 0.8 to $1.6 \mathrm{~g} / 100 \mathrm{~g}$ of solid $\mathrm{C} / \mathrm{MC}$. The $\mathrm{C} / \mathrm{MC}$ film with $1.6 \mathrm{~g} / 100 \mathrm{~g}$ of solid $\mathrm{C} / \mathrm{MC}$ of carbendazim had the lowest moisture content. However, the water absorption property of the $\mathrm{C} / \mathrm{MC}$ films was not significantly different at higher carbendazim contents (3.2 to 4.8 $\mathrm{g} / 100 \mathrm{~g}$ of solid $\mathrm{C} / \mathrm{MC}$ ). The sorption isotherm of the studied films were similar to those of cassava flour films (Kulchan et al., 2010; Mali et al., 2005), methylcellulose, ethylcellulose films (Velaquez de la Cruz et al., 2001), and hydroxypropyl methylcellulose films (Villalobos et al., 2006).

The change in the moisture sorption isotherms of $\mathrm{C} / \mathrm{MC}$ films at different carbendazim contents may be related to changes in the morphology of the cross-section of the films (Figure 3). The cross-section of the C/MC films containing 0.0-0.8 g/100 g solid of C/MC carbendazim were smooth (Figure $3 \mathrm{a}, \mathrm{b}$ ) while they became rougher and less homogenous at 3.3-4.8 (g) carbendazim contents (Figure 3d,e). Compared to C/MC films, the cross-section morphologies of $\mathrm{C} / \mathrm{MC}$ films incorporated with $1.6 \mathrm{~g}$ carbendazim/100 g solid of $\mathrm{C} / \mathrm{MC}$ were rougher but still homogenous (Figure 3c). There was some partial carbendazim insolubility found in the C/MC film solutions. When carbendazim was blended into the films to create the incomplete solubilization, the distribution of carbendazim molecules can reduce the water absorption of chitosan molecules and methylcellulose chains, therefore the equilibrium moisture content decreased. Moreover, the results for the morphology of C/MC films with carbendazim showed that some small phase-separations appeared in the cross-sectional morphology of films containing high carbendazim contents (Figure 3c-e). The presence of small phase-separations of carbendazim in the films may be related to the change of moisture sorption isotherm of these films. 
The GAB, BET and Oswin models were used to fit the water adsorption data of the film and pure components. The calculated model constants, coefficient of determination $\left(\mathrm{r}^{2}\right)$ and \%RMS for each model for each C/MC film with various carbendazim contents are shown in Table 2. Both the GAB and BET models are popularly accepted models for food and edible materials. The GAB model is a semi-theoretical multilayer sorption model with a physical meaning for each constant (Timmermann et al., 2001) which is based on multiple layers and condensed film water while the BET model is based on the monolayer. In Table 2, monolayer water contents of C/MC films incorporated with carbendazim from GAB and BET models were in the range 1.247-1.594 and 1.263-2.011 g water $/ \mathrm{g}$ solids at $25^{\circ} \mathrm{C}$, respectively. The monolayer values indicate that the maximum amount of water that could be absorbed in a single layer per gram of dry film and this is a measure of the number of absorption sites (Strauss et al., 1991). In the GAB models, films without carbendazim presented the highest monolayer value $(1.594 \mathrm{~g}$ water/g solids) while the lowest monolayer value ( $1.247 \mathrm{~g}$ water/g solids) was observed when $1.6 \mathrm{~g} / 100 \mathrm{~g}$ of solid C/MC of carbendazim was incorporated. The Oswin model provided good descriptions of the moisture isotherms through the entire range of water activity (Suppakul, 2006). However, our results showed that the maximum \% RMS value was obtained for the Oswin model, which was $72.844 \%$ for the $\mathrm{C} / \mathrm{MC}$ film incorporated with $4.8 \mathrm{~g}$ carbendazim at $25^{\circ} \mathrm{C}$. Thus, the GAB model was found to be the best estimator for predicting the equilibrium moisture content of $\mathrm{C} / \mathrm{MC}$ films incorporated with carbendazim.

Fig. 4a-e shows the experimental vs. estimated equilibrium moisture contents of C/MC films with various carbendazim amounts. The obtained points lie on the diagonal for low and intermediate $\mathrm{a}_{\mathrm{w}}$ levels, which indicates a low interaction between the components in agreement with their separation in dependent phases as observed during the film drying (Schwartzberg, 1986). At high levels of water activity, it can be observed that some points in Fig. 4a-e, do not lie on the diagonal. These results may relate to the different interactions between water molecules and the polar groups of the films (Tongdeesoontorn et al., 2009; Suppakul, 2006).

\section{Conclusions}

Our results in this study show that when carbendazim is used as an antimicrobial agent it can affect the sorption isotherms of $\mathrm{C} / \mathrm{MC}$ films. The $\mathrm{C} / \mathrm{MC}$ films incorporated with carbendazim exhibited lower water solubility and lower equilibrium moisture contents under all relative humidity conditions. The equilibrium moisture content of all films dramatically increased above $\mathrm{a}_{\mathrm{w}}=0.66$. The pure films incorporated with $1.6 \mathrm{~g} / 100 \mathrm{~g}$ of solid C/MC of carbendazim achieved the lowest solubility value and equilibrium moisture content. The change of the moisture sorption isotherms of these $\mathrm{C} / \mathrm{MC}$ films at different carbendazim contents is related to the change in morphology of the cross-section of the films. The GAB, BET and Oswin sorption models were then used to fit the experimental data. The results show that the GAB model is the best model for predicting the equilibrium moisture content of $\mathrm{C} / \mathrm{MC}$ films incorporated with carbendazim at $25^{\circ} \mathrm{C}$. Knowledge of these results is important for the development of antimicrobial films for fruit storage.

\section{Acknowledgements}

The financial support of The Agricultural \& Science Technology Project-VIE 2283(SF), Ministry of Agriculture and Rural Development, Vietnam are gratefully acknowledged. The authors also want to thank The National Research University Project under Thailand's Office of the Higher Education Commission for financial support. The authors would like to thank Postharvest Technology Research Institute, Chiang Mai University for the research equipments and Dr. Wirongrong Tongdeesoontorn (School of Agro-Industry, Mea Fah Luang University) for reviewing the manuscript.

\section{References}

Al-Muhtaseb, A. H., McMinn, W. A. M., \& Magee, T. R. A. (2004). Water sorption isotherms of starch powders. Part 2: Thermodynamic characteristics. Journal of Food Engineering, 62(2), 135-142. http://dx.doi.org/10.1016/s0260-8774(03)00202-4

Cadden, A. M. (1988). Moisture sorption characteristics of several food fibers. Journal of Food Science, 53(4), 1150-1155. http://dx.doi.org/10.1111/j.1365-2621.1988.tb13550.x

Caner, C., Vergano, P. J., \& Wiles, J. L. (1998). Chitosan film mechanical and permeation properties as affected by acid, plasticizer, and storage. Journal of Food Science, 63, 1049-1053. http://dx.doi.org/10.1111/j.1365-2621.1998.tb15852.x

Chen, M. C., Yeh, G. H. C., \& Chiang. B. H. (1996). Antimicrobial and physicochemical properties of methylcellulose and chitosan films containing a preservative. Journal of Food Processing and Preservation, 20, 379-390. http://dx.doi.org/10.1111/j.1745-4549.1996.tb00754.x 
Cervera, M. F., Karjalainen, M., Airaksinen, S., Rantanen, Jukka, Krogars, K., Heinämäki, J., Colarte, A. I., \& Yliruusi, J. (2004). Physical stability and moisture sorption of aqueous chitosan-amylose starch films plasticized with polyols. European Journal of Pharmaceutics and Biopharmaceutics, 58(1), 69-76. http://dx.doi.org/10.1016/j.ejpb.2004.03.015

Chirife, Jorge, \& Iglesias, Hector A. (1978). Equations for fitting water sorption isotherms of foods: Part 1 - a review. International Journal of Food Science \& Technology, 13(3), 159-174. http://dx.doi.org/10.1111/j.1365-2621.1978.tb00792.x

Clemons, G. P., \& Sisler, H. D. (1971). Localization of the site of action of a fungitoxic benomyl derivative. Pesticide Biochemistry and Physiology, 1(1), 32-43. http://dx.doi.org/10.1016/0048-3575(71)90209-4

Donhowe, I., \& Fennema, O. (1993). The effect of plasticizers on crystallinity, permeability and mechanical properties of methylcellulose films. Journal of Food Processing and Preservation, 17, $247-257$. http://dx.doi.org/10.1111/j.1745-4549.1993.tb00729.x

García, M. A., Pinotti, A., Martino, M. N., \& Zaritzky, N. E. (2004). Characterization of composite hydrocolloid films. Carbohydrate Polymers, 56(3), 339-345. http://dx.doi.org/10.1016/j.carbpol.2004.03.003

Goldberg, S., Doyle, R. J., \& Rosenberg, M. (1990). Mechanism of enhancement of microbial cell hydrophobicity by cationic polymers. Journal of Bacteriology, 172(10), 5650-5654.

Mali, S., Sakanaka, L. S., Yamashita, F., \& Grossmann, M. V. E. (2005). Water sorption and mechanical properties of cassava starch films and their relation to plasticizing effect. Carbohydrate Polymers, 60(3), $283-289$. http://dx.doi.org/10.1016/j.carbpol.2005.01.003

Lai, H. M., \& Padua, G. W. (1998). Water vapor barrier properties of zein films plasticized with oleic acid. Cereal Chemistry, 75, 194-199.

Ludwiczak, S., \& Mucha, M. (2010). Modeling of water sorption isotherms of chitosan blends. Carbohydrate Polymers, 79(1), 34-39. http://dx.doi.org/10.1016/j.carbpol.2009.07.014

Park, H. J., Weller, C. L., Vergano, P. J., \& Testin, R. F. (1993). Permeability and mechanical properties of cellulose-based edible films. Journal of Food Science, 58, 1361-1364.

Rachtanapun, P. (2007). Shelf life study of salted crackers in pouch by using computer simulation model. Chiang Mai Journal Science, 34(2), 209-218.

Rachtanapun, P., \& Tongdeesoontorn, W. (2009). Moisture sorption isotherms and wator vapor permeability of carboxymethyl cellulose from papaya peel/cornflour blended films. Asian Journal of Food and Agro-Industry, 2(04), 791-801.

Rachtanapun, P., Kumsuk, N., Thipo, K., \& Lorwatcharasupaporn, P. (2010). Prediction models for shelf life of pumpkin crackers in different packages based on its moisture content. Chiang Mai Journal of Science, 37(3), 410-420.

Ratchaneewan, K., Waraporn, B., \& Suppakul, P. (2010). Shelf life prediction of packaged cassava-flour-based baked product by using empirical models and activation energy for water vapor permeability of polyolefin films. Journal of Food Engineering, 100(3), 461-467. http://dx.doi.org/10.1016/j.jfoodeng.2010.04.031

Sangsuwan, J., Rattanapanone, N., \& Rachtanapun, P. (2008). Effects of vanillin and plasticizer on properties of chitosan-methyl cellulose based film. Journal of Applied Polymer Science, 109(6), 3540-3545. http://dx.doi.org/10.1002/app.28461

Schwartzberg, H. G. (1986). Modeling of gas and vapour transport through hydrophilic films. In M. Mathlouthi (Ed.), Food packaging and preservation: theory and practice. Elsevier, London. pp.115.

Strauss, U. P., Porcja, R. J., \& Chen, Y. (1991). Volume effects of starch water interactions. In H. Levine, L. Slade (Eds.), Water relationships in foods (pp. 351-364). New York: Plenum Press.

Suppakul, P. (2006). Moisture sorption characteristics of cassava flour film. Proceedings of 15th IAPRI World Conference on Packaging (pp. 113-117), Tokyo, Japan.

Timmermann, E. O., Chirife, J., \& Iglesias, H. A. (2001). Water sorption isotherms of foods and foodstuffs: BET or GAB parameters. Journal of Food Engineering, 48(1), 19-31. http://dx.doi.org/10.1016/s0260-8774(00)00139-4 
Tongdeesoontorn, W., Mauer, J. L., Wongruong, S., \& Rachtanapun, P. (2009). Water vapor permeability and sorption isotherms of cassava starch based films blended with gelatin and carboxymethyl. Asian journal of Food and Agro-Industry, 2(04), 501-514.

Torres, J. A. (1994). Edible coating and films from proteins. In Hettiarachchy, A., Ziegler, G. (Ed). Protein functionality in food systems (p. 467). IFT/Marcel Dekker Press, New York.

Turhan, K. N., \& Sahbaz, F. (2004). Water vapor permeability, tensile properties and solubility of methylcellulose-based edible films. Journal of Food Engineering, 61(3), 459-466. http://dx.doi.org/10.1111/j.1365-2621.2001.tb15581.x

Velaquez de la Cruz, G., Torres, J. A., \& Martin-Polo, M. O. (2001). Temperature effect on the moisture sorption isotherms for methylcellulose and ethylcellulose films. Journal of Food Engineering, 48(1), 91-94. http://dx.doi.org/10.1016/S0260-8774(00)00143-6

Villalobos, Ricardo, Hernández-Muñoz, Pilar, \& Chiralt, Amparo. (2006). Effect of surfactants on water sorption and barrier properties of hydroxypropyl methylcellulose films. Food Hydrocolloids, 20(4), 502-509. http://dx.doi.org/10.1016/j.foodhyd.2005.04.006

Table 1 . Relative humidity control chamber using saturated salt solutions at $25 \pm 0.5^{\circ} \mathrm{C}$

\begin{tabular}{lll}
\hline \multicolumn{1}{c}{ Saturated salt solutions } & $\begin{array}{l}\text { Equilibrium (Expected) } \\
\text { \% RH }\end{array}$ & $\begin{array}{l}\text { Actual reading } \\
\text { \% RH }\end{array}$ \\
\hline 1. Lithium Chloride & 11.30 & $11.2 \pm 0.16$ \\
2. Magnesium Chloride & 32.78 & $33.5 \pm 0.20$ \\
3. Potassium Carbonate & 43.16 & $44.5 \pm 0.20$ \\
4. Magnesium Nitrate & 52.89 & $53.1 \pm 0.19$ \\
5. Sodium Nitrate & 64.00 & $66.4 \pm 0.17$ \\
6. Sodium chloride & 75.29 & $75.1 \pm 0.50$ \\
7. Potassium Chloride & 84.24 & $85.5 \pm 0.09$ \\
\hline
\end{tabular}

Table 2. Parameters, regression coefficient $\left(\mathrm{r}^{2}\right)$ and root mean square percent error (\%RMS) of the GAB, BET and Oswin models for moisture absorption isotherms of chitosan/methylcellulose incorporated with carbendazim at 25 $\pm 0.5^{\circ} \mathrm{C}$

\begin{tabular}{|c|c|c|c|c|c|c|}
\hline \multirow[t]{2}{*}{ Model } & \multirow[t]{2}{*}{ Parameter } & \multicolumn{5}{|c|}{$\begin{array}{l}\mathrm{C} / \mathrm{MC} \text { films with various carbendazim contents } \\
\text { (g carbendazim/100g of solid } \mathrm{C} / \mathrm{MC} \text { ) }\end{array}$} \\
\hline & & 0.0 & 0.8 & 1.6 & 3.2 & 4.8 \\
\hline \multirow[t]{5}{*}{ GAB } & $M_{o}$ & 1.5954 & 1.5244 & 1.2470 & 1.3728 & 1.4120 \\
\hline & $C$ & 5.0351 & 5.4984 & 11.0025 & 19.4962 & 24.5278 \\
\hline & $k$ & 1.0294 & 1.0148 & 1.0022 & 1.0132 & 1.0368 \\
\hline & $r^{2}$ & 0.9953 & 0.9927 & 0.9965 & 0.9952 & 0.9963 \\
\hline & $\% R M S$ & 36.0854 & 33.5455 & 21.7048 & 16.5666 & 14.1190 \\
\hline \multirow[t]{4}{*}{ BET } & $M_{o}$ & 2.0117 & 1.6932 & 1.2632 & 1.4814 & 1.8218 \\
\hline & $C$ & 2.0216 & 3.4094 & 10.1001 & 10.6873 & 3.8258 \\
\hline & $r^{2}$ & 0.9937 & 0.9923 & 0.9964 & 0.9943 & 0.9898 \\
\hline & $\% R M S$ & 60.2186 & 46.2565 & 23.4484 & 27.2380 & 53.8464 \\
\hline \multirow[t]{4}{*}{ Oswin } & $M_{o}$ & 2.6011 & 2.5205 & 2.2450 & 2.5874 & 2.6749 \\
\hline & $C$ & 0.8983 & 0.8349 & 0.7477 & 0.7617 & 0.8506 \\
\hline & $r^{2}$ & 0.9928 & 0.9908 & 0.9929 & 0.9878 & 0.9854 \\
\hline & $\% R M S$ & 66.7071 & 59.9128 & 54.1385 & 61.1629 & 72.8441 \\
\hline
\end{tabular}




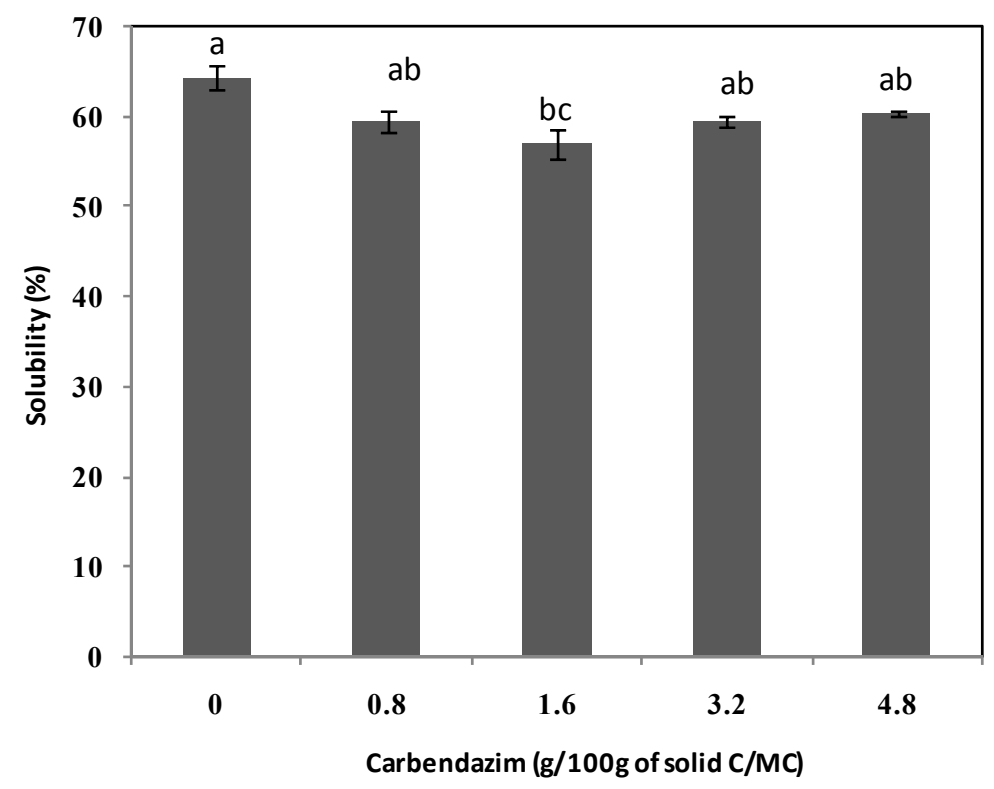

Figure 1. Solubility of chitosan/methylcellulose containing different levels of carbendazim at $25 \pm 0.5^{\circ} \mathrm{C}$

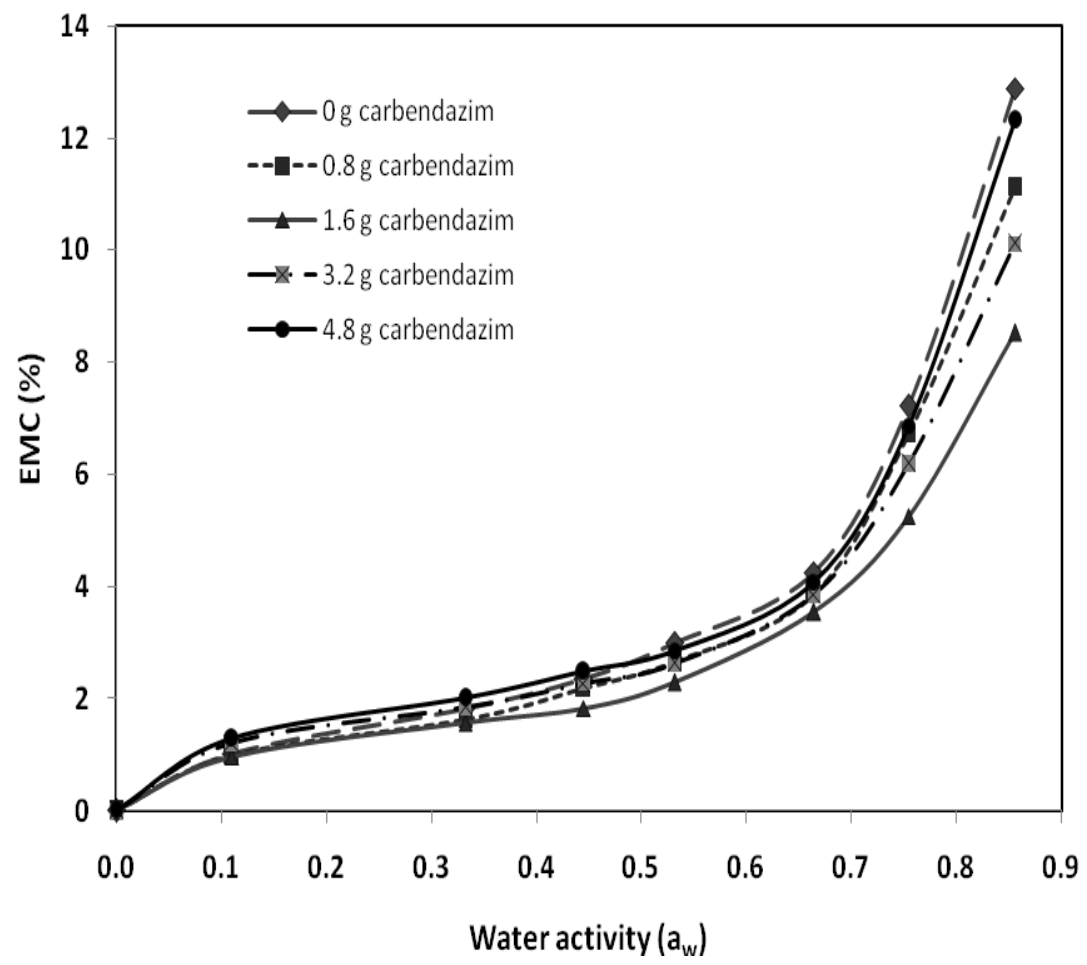

Figure 2. Moisture sorption isotherms of chitosan/methylcellulose films incorporated with carbendazim $(\mathrm{g} / 100 \mathrm{~g}$ of solid $\mathrm{C} / \mathrm{MC}$ ) at $25 \pm 0.5^{\circ} \mathrm{C}$ 

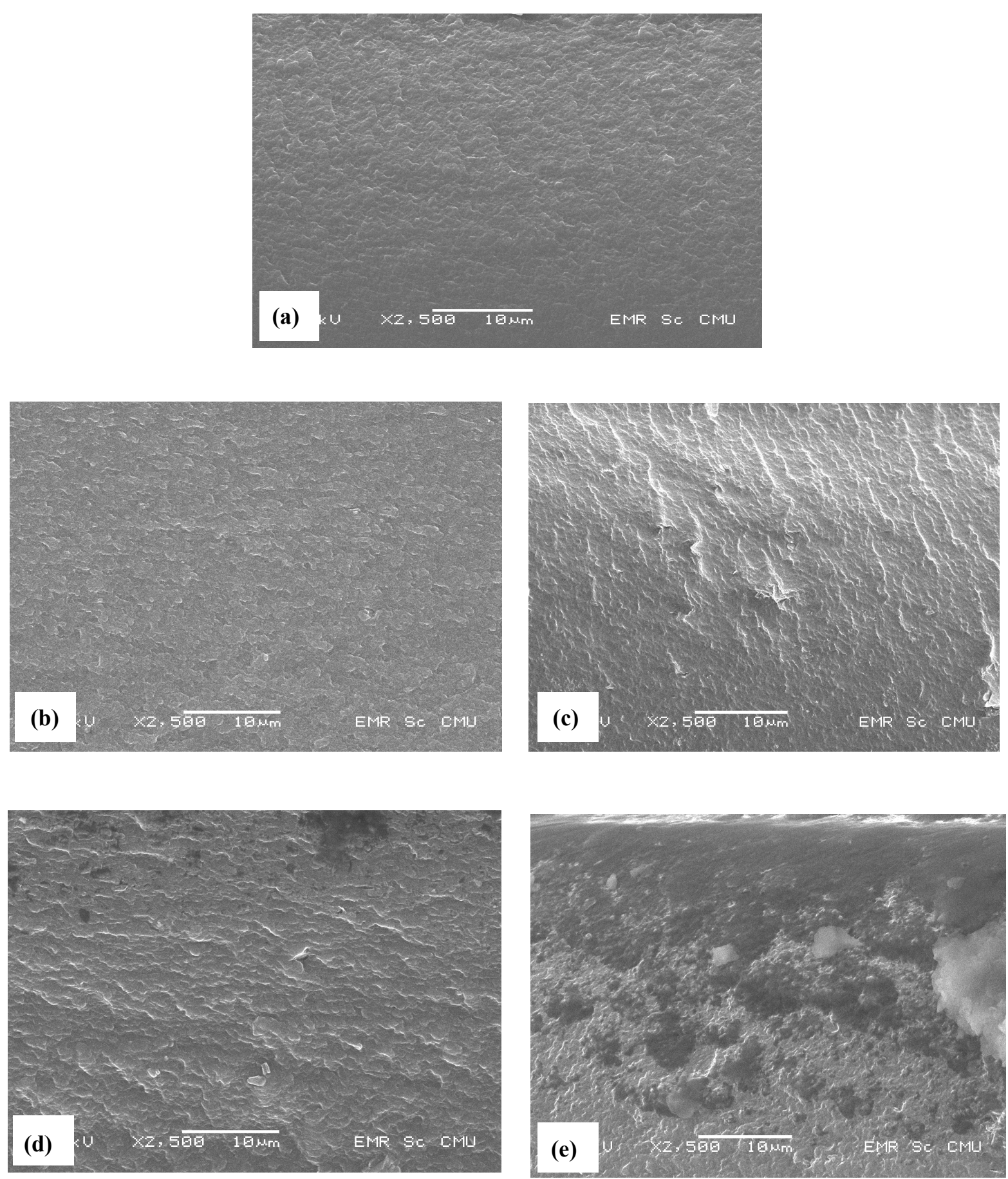

Figure 3. The cross-section morphologies of chitosan/methylcellose films incorporated with various carbendazim contents at 2500x: (a) 0.0; (b) 0.8; (c) 1.6; (d) 3.2 and (e) $4.8 \mathrm{~g} / 100 \mathrm{~g}$ solid of C/MC 

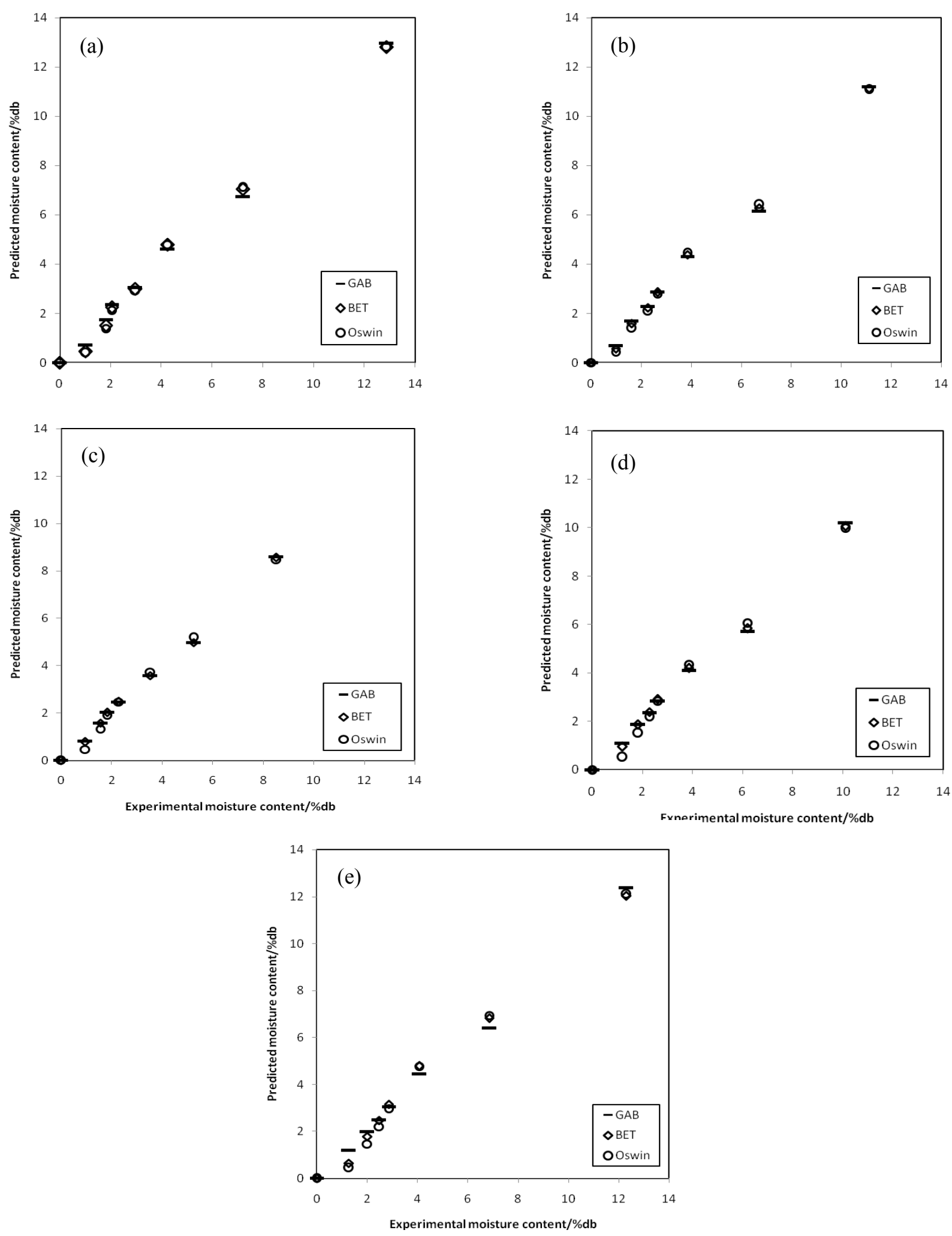

Figure 4. Comparison between the experimental moisture content and those predicted by various sorption isotherm models for chitosan/methylcellulose incorporated with various carbendazim contents: (a) 0.0; (b) 0.8; (c) 1.6 ; (d) 3.2 and (e) $4.8 \mathrm{~g} / 100 \mathrm{~g}$ of solid C/MC at $25^{\circ} \mathrm{C}$ 